\title{
ЗАРУБІЖНИЙ ДОСВІД ПРОФІЛАКТИКИ ПРАВОПОРУШЕНЬ СЕРЕД НЕПОВНОЛІТНІХ
}

УДК: 159:343.224.1

\section{Мураненко Катерина Юрї̈на}

\author{
Викладач кафедри юридичної психології, Наџіона- \\ льна академія внутрішніх справ, м. Київ (Украӥна) \\ ORCID ID: https://orcid.org/0000-0001-6032-243X
}

\begin{abstract}
Анотація. У статті представлено аналіз системи профілактики правопорушень серед неповнолітніх зарубіжних країн та визначено основні аспекти ефективної профілактики правопорушень, на які необхідно звернути увагу в процесі становлення системи профілактики правопорушень серед неповнолітніх в Україні. Профілактичні системи Великобританії, Франції, Німеччини, Японї описуються згідно чотирьох базових концепцій превенції молодіжної злочинності. У Німеччині, як і у полійї Нідерландів, профілактика правопорушень неповнолітніх поєднує каральну та ресочіалізаџійну моделі. Яскравим прикладом ресоиіалізаційної парадигми превенції молодіжної злочинності є Японія. Проте японська поліція не оминає увагою необхідність взаємодії різних органів та установ. Громадсько-інтеграційна модель профілактики правопорушень відображена у законодавстві Великобританії. Франція $є$ прикладом реституиійної парадигми. Однак у ичих системах профілактики спостерігаються виражені ознаки інших підходів. Тобто ефективним є поєднання проявів різних моделей превенції правопорушень неповнолітніх, при цьому система профілактики правопорушень має бути цілісною та скоординованою. Аналіз ефективних профілактичних систем вказує на необхідність звернути увагу на такі складові як правове поле, спеціалізовані суди та спеціальні суб'єкти профілактики правопорушень неповнолітніх.
\end{abstract}

Ключові слова: правопорушення неповнолітніх, молодіжна злочинність, профілактика правопорушень, зарубіжний досвід, карально-репресивна модель, ресочіалізаційна парадигма, реституиійний підхід, громадсько-інтеграційна модель.

Постановка проблеми. Аналізуючи делінквентну поведінку неповнолітніх, вчені сходяться на думці, що на поведінку дитини впливають різноманітні чинники: соціальноекономічні, біологічні, психологічні тощо. Профілактика правопорушень серед неповно- 
літніх являє собою розгалужену систему, що враховує усі можливі причини формування делінквентної поведінки.

Психологічний аспект профілактики правопорушень неповнолітніх вивчали А. Бандура, С. Д. Максименко, В. М. Синьов, I. А. Фурманов, С. І. Яковенко та ін. На організаційно-правову основу системи профілактики правопорушень серед дітей звертали увагу Р. М. Абизова, Г.А. Аванесова, А.І. Алексєєва, О. Б. Андрєєва, М.М. Бабаєва, О.М. Бандурка, В. В. Голіни, Л.М. Давиденко, І.М. Даньшин, Г. М. Міньковський, B.М. Трубников, В. І. Шакун та ін.

У сфері правопорушень, що вчиняються дітьми, українське законодавство регламентує вік, з якого настає адміністративна, цивільна, кримінальна відповідальність, покарання, які можуть бути застосовані до неповнолітніх за протиправні діяння. Однак, на сучасному етапі в Україні немає чіткої системи профілактики правопорушень серед неповнолітніх. Ми вважаємо за необхідне звернутися до успішного досвіду інших країн, проаналізувати ефективні моделі профілактики правопорушень та визначити основні аспекти, на які варто звернути увагу при побудові вітчизняної профілактичної системи правопорушень неповнолітніх.

Мета статті - проаналізувати ефективні системи профілактики правопорушень серед неповнолітніх у високорозвинених країнах світу та визначити основні аспекти, на які необхідно звернути увагу у процесі реформування профілактичної системи в Україні.

Виклад основного матеріалу. Кожна держава зацікавлена, насамперед, у створенні передумов, які б сприяли недопущенню вчинення правопорушень, ніж застосуванні покарання до винних після їх вчинення, особливо якщо правопорушники - діти. 3 огляду на це, надзвичайно важливим у контексті створення в Україні оптимальної законодавчої бази, здатної забезпечити ефективну протидію правопорушенням неповнолітніх, $\epsilon$ використання позитивного правотворчого досвіду в окресленій сфері провідних країн світу. Ще в давні часи просвітителі XVIII ст. Ч. Беккаріа та Ш. Монтеск'є сформулювали положення, згідно з яким мудрий законодавець повинен турбуватися не стільки про покарання за злочин, скільки про створення системи запобіжних заходів, які б сприяли недопущенню протиправних дій. Вольтер акцентував увагу на тому, що запобігання правопорушень має бути істинним призначенням юстиції цивілізованого суспільства.

Розглянемо основні аспекти профілактики правопорушень неповнолітніх зарубіжних країн, спираючись на концепцію чотирьох базових моделей-парадигм превенції молодіжної злочинності С.Ф. Денисова, де виділяються карально-репресивна, громадськоінтеграційна, ресоціалізаційна та реституційна моделі [4].

Найбільш звичною та зрозумілою в ук- 
раїнських реаліях $є$ традиційно каральнорепресивна концепція, сутність якої полягає в удосконаленні існуючих кримінальноправових технологій, орієнтованих в основному на примус і силовий тиск на злочинців через засоби нагляду й контролю. Це підтверджується адміністративним, кримінальним законодавством, яке передбачає покарання неповнолітніх за вчинення правопорушень (адміністративна та кримінальна відповідальність наступає з 16 років). Крім того, в Україні діє розгалужена система суб'єктів профілактики правопорушень, які насправді мають на меті відокремлення неповнолітніх правопорушників від суспільства, що за своєю суттю більше схоже на покарання, аніж на методи профілактики. До них належать: приймальники розподільники, школи та професійні училища соціальної реабілітації, спеціальні виховні установи Державної кримінально-виконавчої служби України, притулки для дітей тощо. Незважаючи на те, що система профілактики правопорушень неповнолітніх в Україні не є ефективною, не можна стверджувати, що каральний аспект є недоцільним. Варто зазначити, що певні прояви карального підходу спостерігаються і у високорозвинених країнах, профілактичні системи правопорушень неповнолітніх у яких вважаються еталонними. Так, застосування карального підходу спостерігається у системі профілактики правопорушень неповнолітніх у Німеччині.

На території Північної Рейн-Вестфалії в управлінні поліції утворені спеціальні комісаріати по розслідуванню злочинів, пов'язаних 3 наркотиками, зайняттям проституцією, розшуком безвісти зниклих, а також правопорушень, вчинених дітьми. Комісаріати уповноважені займатися категорією справ, у яких частіше за все фігурують діти. Контроль та загальна координаційна робота здійснюється безпосередньо управлінням поліції. В інформаційній системі управління кримінальної поліції накопичений спеціальний масив відомостей про протиправні вчинки дітей. На його основі здійснюється аналіз причин та характерних особливостей розвитку злочинності серед підлітків. Результати цих досліджень використовуються при підготовці та перепідготовці працівників, а також проваджуються в начальний процес.

В той же час на інших землях ФРН спостерігається більш м'який підхід до малолітніх правопорушників. На території землі Нижня Саксонія поліція при розслідуванні справ про правопорушення неповнолітніх працює в тісному контакті з іншими соціальними службами. На землі Саар 3 правопорушникамипідлітками працюють жінки-поліцейські, які проходять курс спеціальної підготовки.

Досить високий рівень здійснення профілактики дитячої злочинності досягнутий в Західному Берліні. Для роботи з неповнолітнім у складі управління поліції створений спеціальний комісаріат, який здійснює реагування на всі доноси та протоки стосовно дітей. 
Працівники комісаріату не тільки розслідують справи й проводять профілактичну роботу з неповнолітніми [1, с.185-187].

В основу стратегії профілактики правопорушень неповнолітніх у Німеччині покладено позицію, що схильність дитини до правопорушень є тимчасовим проявом, а репресивні заходи лише негативно впливають на становлення особистості, Проте зважаючи на розвиненість німецької системи правоохоронних органів з питань розслідування злочинів неповнолітніх, варто зазначити, що каральний підхід також є значущим, однак основний акцент все ж здійснено на пошук причин та профілактику правопорушень серед дітей, що $\epsilon$ характерними ознаками ресоціалізаційного підходу.

У поліції Нідерландів також поєднані каральний та профілактичний підхід, при чому ці функції здійснюються різними суб'єктами. Штат підрозділу у справах неповнолітніх поліції Нідерландів, який займається розслідуванням злочинів, що вчиняються неповнолітніми, формується із врахуванням гендерної політики, тобто передбачає однакову кількість чоловіків та жінок, досвід роботи кожного працівника у цій сфері діяльності повинен становити не менше 5 років. До підрозділу зараховуються офіцери, які успішно пройшли відповідні тренінги 3 дитячої психології та основ роботи 3 неповнолітніми. А от для здійснення профілактичної функції спеціально створений підрозділ превенції, що входить до структури управління охорони громадської безпеки[1].

Іншою парадигмою профілактики правопорушень неповнолітніх є ресоціалізаційна модель, сутність якої полягає в створенні спеціальних заходів відстрочки кримінальної репресії молодих злочинців із застосуванням щодо них технологій повторної правової соціалізації (ресоціалізації) через спеціально створювані реабілітаційно-виховні центри;

Яскравим прикладом ресоціалізаційного підходу є Японія. Ювенальна юстиція Японії побудована та діє на основі нормативноправового акта 1949 року, який має назву «Шоненьо». Він регламентує порядок захисту і реалізації конституційних прав усіх неповнолітніх віком до 20 років, зосереджуючи при цьому головну увагу на неповнолітніх правопорушниках.

Система ювенальної юстиції Японії складається з таких елементів: служба пробації; сімейні суди; пенітенціарні установи для дітей та молоді. На окремих етапах провадження у ювенальних справах підключається прокуратура. Пенітенціарні установи мають чотири рівні, пристосовані до вікових особливостей правопорушників:

- установи першого рівня (для правопорушників 14 - 16 років);

- установи середнього рівня (для правопорушників 16 - 23 років);

- спеціальні установи (для правопорушників віком від 16 років, які вчинили тяжкі 
злочини);

- медичні установи (для правопорушників 14 - 26 років із фізичними та розумовими вадами).

«Шоненьо» має чітко виражену захисну, а не каральну дію. Так у законі не міститься жодного положення про покарання неповнолітнього, йдеться лише про необхідність його перевиховання. Юридичні терміни, використані в «Шоненьо», також підтверджують захисний характер цього документа. Наприклад, замість терміна «злочин, вчинений неповнолітньою особою» використовується термін «злочин, який свідчить про необхідність захисту неповнолітньої особи». Замість терміна «судові слухання у справі» використано термін «процес щодо захисту неповнолітньої особи». А суть покарання, на думку законодавця, полягає в тому, що неповнолітній має пройти процес перевиховання, навіть якщо він цього не бажає [7, с. 91-93]. Незважаючи на розгалужену систему пенітенціарних установ, спрямованих на роботу з неповнолітніми, Японія $\epsilon$ прикладом ресоціалізаційного підходу.

Особливе місце у попередженні правопорушень у Японії займає поліція, особливо патрульно-постова служба, яка постійно взаємодії з населенням. Ефективним засобом профілактики правопорушень є так звані «пункти зв'язку з поліцією», у які входять члени добровільних асоціацій громадян. Кожний пункт охоплює близько 50 родин, усього таких пунктів приблизно 700 тис. Найбільша громадська організація в сфері попередження правопорушень і співпраці 3 органами поліції «Федерація попередження злочинності», що складається з 50 асоціацій на рівні префектур, 1200 районних відділів при управліннях поліції, 410 тис. місцевих відділень при поліцейських дільницях. «Федерація попередження злочинності» проводить різні заходи щодо попередження правопорушень неповнолітніх, організують із числа своїх членів «загони пильності», що патрулюють по вулицях у вечірній $\mathrm{i}$ нічний час.

Отже, окрім виражених проявів ресоціалізаційної моделі, профілактична система Японії містить і громадсько-інтеграційний аспект, оскільки звертає особливу увагу на взаємодію між різними органами та системами. Науковці підтверджують, що таке поєднання $€$ дієвим. Офіційна статистика та результати соціологічних досліджень у Японії свідчить про те, що із всіх осіб, які перебували під опікою несудових органів, лише $23 \%$ знову вчинили правопорушення, причому 16\% 3 них були притягнуті до відповідальності за дорожньотранспортні порушення. Переважна ж більшість таких неповнолітніх у майбутньому не вчиняють жодних правопорушень [6, с.79-80].

Сутність громадсько-інтеграційної моделі полягає в координації зусиль державних правоохоронних органів та місцевих громад, спрямованих на усунення або мінімізацію чинників молодіжної злочинності шляхом проведення виховної роботи, покращання жи- 
тлових умов, надання психотерапевтичних консультацій проблемним молодим людям із незаможних, неповних та асоціальних сімей тощо).

Найбільш вираженою зазначена концепція є у профілактичній системі Великобританії. Робота $з$ неповнолітніми, схильними до протиправної поведінки, а також із неблагополучними сім'ями, забезпечується, насамперед, правоохоронними органами та соціальною службою і полягає в організації відповідних профілактично-корекційних заходів.

У випадку виявлення неблагополучної сім'ї, в якій не створені належні умови для нормального розвитку дитини, більше того, де iї ображають, карають чи взагалі не звертають на неї уваги, що починає негативно позначатися на поведінці дитини, її тимчасово вилучають із сім'ї. Найбільш поширеними в подібних випадках заходами є “fostering" (або «виховання»)та “mainstay” (дослівно «опора»). Суть їх в тому, що вони означають догляд за чужою дитиною, особливий вид опікунства. “Fostering” передбачає перебування в чужій сім'ї протягом тривалого періоду часу, як правило, до повноліття. Проте контакти дитини із справжніми батьками зберігаються, і як тільки умови в сім’ї стають більш сприятливими для виховання дитини, вона знову повертається в сім’ю. “Mainstay” передбачає догляд за дітьми від 11 до 17 років на коротший період, найчастіше - це всього кілька місяців, у зв'язку з тимчасовими труднощами в сім'ї дитини. Як- що ці труднощі зникають, дитина повертається в сім'ю, якщо ж сім'я продовжує переживати важкий період, то оформляється “fostering”, тобто довготривале виховання.

Крім того, існує ще й інший вид догляду за дітьми 3 неблагополучних сімей "emergency care" - догляд в надзвичайних (критичних) ситуаціях. Він має місце тоді, коли виникає необхідність негайно ізолювати дитину від негативного впливу сім'ї, наприклад, в сім’ї трапилося що-небудь екстраординарне (вбивство, арешт, дорожньотранспортна аварія тощо). В таких випадках дитина передається для догляду в іншу сім'ю на кілька днів чи тижнів до остаточного вирішення питання про іiї подальшу долю. Люди, які в будь-який час готові прийняти в свою сім’ю чужу дитину, називаються “carers” (або «піклувальники»). Такими можуть бути сімейні і одинокі люди, яким виповнилося 25 років і які виявили бажання виховувати чужих дітей. У Великобританії відсутня система дитячих будинків та інтернатів, адже вважається, що нормальний розвиток дитини краще забезпечується в сім'ї, нехай навіть чужій. Ми погоджуємося із наведеною думкою.

В тих випадках, де це можливо, дитина залишається у своїй сім’ї. В такому випадку проводиться інтенсивна індивідуальна психотерапевтична, консультативна робота, в залежності від труднощів, які переживає родина. Сім'я перебуває під постійним контролем соціального працівника, відвідує заняття в спе- 
ціальних консультативних центрах із питань сім’ї, які є у кожному місті. Отже, ми бачимо успішний приклад об'єднання громади задля профілактики правопорушень неповнолітніми.

Політика Великобританії щодо профілактики правопорушень серед дітей є відображенням громадського-інтеграційного підходу. Однак, спостерігаються тут і ознаки ресоціалізаційних тенденцій. Адже, окрім вищезазначених шляхів профілактики, велика увага приділяється дітям, у поведінці яких вже проявилися певні відхилення, якими були скоєні проступки, незначні правопорушення. Проте значна увага приділяється не покаранню, а профілактиці правопорушень, виявленні проявів девіантності на ранніх стадіях.

У випадку здійснення злочину неповнолітнім до 16 років справа не розглядається в суді. Для цього існує система “Children's Panels" (дитячих комісій) та “Children's Hearings" (дитячих слухань). “Children's Panels" - це спеціальна комісія, що складається 3 людей (переважно віком від 25 до 50 років), які мають певні знання в галузі психології, педагогіки, навички спілкування 3 дітьми. Робота в цій комісії вважається надзвичайно відповідальною, тому члени комісії призначаються Державним Секретарем строком на п'ять років. Вони проходять спеціальну підготовку за відповідними програмами.

Як правило, члени такої комісії забезпечують роботу й “Children's Hearings" - процес слухання дитячих справ, в якому беруть участь три члени комісії. Слухання найчастіше відбувається в сім'ї, за місцем проживання, в присутності батьків і дитини, поведінка яких обговорюється. Перед цим дитину глибоко і всебічно вивчають. У результаті слухання приймаються рішення стосовно іiі майбутнього: вона може бути залишена в сім'ї, але перебувати під наглядом соціального працівника, або буде передана під опіку іншої сім'ї, іноді направлена в спеціальну школу для дітей 3 відхиленнями в поведінці. У таких школах діти можуть перебувати від кількох місяців до кількох років, залежно від того, чи є позитивні зміни в їх поведінці.

У деяких випадках діти 3 незначними відхиленнями у поведінці продовжують навчатися у своїй школі, але після обіду вони обов'язково відвідують спеціальні Центри соціальної роботи, де з ними працюють спеціалісти за індивідуальною програмою [1].

Взаємозв'язок та співпраця різних служб та установ спостерігається не лише у Великобританії, а й у Швеції, Швейцарії та Японії, де у навчальних закладах діють комітети зв'язку школи 3 поліцією, до праці в яких залучені батьки, вчителі, близькі родичі та здійснюють профілактичну діяльність серед учнів. У сучасних умовах все більшого оберту набуває практика розповсюдження підліткових клубів поліції. Працівники поліції організовують у них гуртки, проводять спортивні та розважальні заходи, зустрічі з батьками на правову тематику. Створення подібних клубів започат- 
ковано на одній із сесій Конгресу ООН.

Поліція Швейцарії для більш тісної взаємодії в питаннях профілактики підписує протоколи взаємодії із середніми школами. Згідно з цим протоколом школа повинна реалізувати всі можливості для проведення профілактичної роботи з підлітками, які перебувають у конфлікті з законом і лише після цього звертатися до поліції. Крім цього, школа зобов'язана систематично нагадувати правила поведінки дітям, якщо говорити юридичними термінами - проводити правове виховання дітей.

У низці країн Європейського Союзу (Великобританія, Нідерланди, Італія, Німеччина) координування заходів запобігання правопорушенням на центральному рівні здійснюють міністерства внутрішніх справ та юстиції. Спеціальні підрозділи, які функціонують у їхній структурі (наприклад, департаменти запобігання злочинності у міністерстві юстиції Нідерландів і міністерстві внутрішніх справ Великобританії) надають допомогу у розробці заходів запобігання правопорушенням на місцевому рівні, координують політику спрямовану на допомогу жертвам протиправних дія, контролюють та координують приватну індустрію технічних засобів захисту від злочинності, а також координують діяльність поліції у сфері запобігання протиправній діяльності.

Варто наголосити, що в Інструкції 3 організації роботи підрозділів ювенальної превенції Національної поліції України, затвердженої Наказом Міністерства внутрішніх справ України №1044 від 19.12.2017 особливу увагу приділено взаємодії підрозділів ювенальної превенції 3 іншими уповноваженими органами та підрозділами Національної поліції України, органами державної влади та місцевого самоврядування, об'єднаними територіальними громадами, міжнародними та громадськими організаціями. Однак законодавство передбачено лише декілька шляхів співпраці, а саме участь у спільних заходах, організація профілактичних заходів для дітей у партнерстві та обмін інформацією.

Цікавою $є$ реституційна парадигма, сутність якої полягає в дедраматизуванні самого факту вчинення злочину і вжиття заходів щодо примирення винуватця і жертви злочину 3 подальшим застосуванням щодо молодого злочинця заходів перевиховання в тій соціальній групі, в якій він спочатку перебував. Певні прояви цієї моделі спостерігаються у профілактичній системі Франції. Характерною особливістю французької моделі ювенальної юстиції є те, що суддя займається не тільки правопорушниками, але й дітьми, які потрапили у соціально небезпечну ситуацію, ще до здійснення протиправного діяння. Значна частина всієї роботи судді проходить не в залі суду, а в його кабінеті. Саме там суддя намагається налагодити контакт із дитиною, а потім спільно 3 нею шукає шляхи виходу із тієї ситуації, що склалася, залучаючи до цього процесу різно- 
манітні соціальні служби. До формальної судової процедури суддя вдається досить рідко, коли всі інші можливості вичерпані. Саме тому французьке ювенальне правосуддя інколи називають «кабінетним правосуддям». Отже, французька система профілактики правопорушень серед дітей є прикладом реституційного підходу. В даному випадку увага акцентується на можливостях відновлювального правосуддя та медіації у правових стосунках з метою профілактики правопорушень неповнолітніх.

Важливе місце у сфері профілактики правопорушень серед дітей займає Управління юридичним захистом молоді, яке належить до Управління міністерства юстиції Франції. Основними завданнями управління $є$ виховання неповнолітніх та попередження вчинення ними правопорушень, виховання і навчання неповнолітніх, які вчинили правопорушення, а також робота 3 повнолітніми, які не досягли 21 року, або мають певні проблеми в житті. Крім того, управлінню належить функція контролю за адміністративною, фінансовою та педагогічною діяльністю служб юридичного захисту молоді [5, с. 58-59].

Необхідно зазначити, що законодавство про адміністративну відповідальність та профілактика адміністративних правопорушень зокрема, як інститут адміністративного права притаманне лише країнам Східної Свропи. Законодавство країн Заходу під адміністративною відповідальністю передбачає інші відносини у порівнянні з законодавством Ук- раїни. За нормативно-правовою базою держав Західної Свропи всі протиправні діяння підпадають під поняття «кримінальне правопорушення», але у ньому виділяються проступки, які не тягнуть за собою таких наслідків як судимість [2, с. 166-161].

Нормами кримінального права в багатьох країнах світу переслідуються не тільки злочини, але й діяння, які згідно з українським законодавством злочинами не вважаються. Наприклад, у праві таких країн, як Франція, Великобританія, Німеччина чіткого розмежування між поняттям «злочин» $\mathrm{i}$ «адміністративне правопорушення» не існує. Французьким кримінальним правом прийнята наступна класифікація правопорушень: просте порушення (contrevention), проступок (délit), злочин (crime).

За своїм юридичним змістом «порушення» згідно 3 французьким законодавством наближене до українського поняття «адміністративне правопорушення. До «порушень» французьке кримінальне право відносить, зокрема, порушення правил дорожнього руху та пов'язану з ними заподіяну шкоду, дрібне хуліганство та інші порушення громадського порядку, тобто безліч діянь, які згідно з українським законодавством віднесені до адміністративних правопорушень.

Характерною особливістю французького законодавства $\epsilon$ те, що будь-яке протиправне діяння є об'єктом регулювання Кримінального кодексу. Справи, що розглядаються ор- 
ганами адміністративної юстиції, закінчуються не покаранням якої-небудь особи, а скасуванням адміністративного акту або його зміною. У цьому випадку адміністративна відповідальність розуміється не як відповідальність громадян, а як відповідальність держави, посадових осіб [3, с. 220-258; 8, с. 54-61].

Висновок. Таким чином, досвід діяльності спеціалізованих суб'єктів, які здійснюють профілактику правопорушень серед неповнолітніх, здійснюється за трьома основними напрямами:

- створення правового поля для діяльності інституту ювенальної юстиції, впровадження нових соціальних технологій, соціально-правових конструкцій;

- створення спеціалізованих судів, що відіграють у системі профілактики правопорушень неповнолітніх організуючу та координуючу роль;

- утворення спеціальних суб'єктів профілактики, в тому числі в структурі поліцейських органів, а також виконання поліцією поряд 3 традиційними функціями не притаманних їм суто функції.

Аналіз правових систем і норм розвинених зарубіжних країн з профілактики правопорушень серед дітей, доводить, що практично скрізь діє єдина скоординована, цілісна система попередження правопорушень неповнолітніх осіб та притягнення їх до юридичної та інших видів відповідальності. Зусилля всіх державних органів у даному випадку, спрямо- вані на вирішення однієї складної глобальної проблеми, яка набула пріоритетності в усьому світі. Політика Великобританії є яскравим прикладом громадсько-інтегративного підходу профілактики правопорушення неповнолітніх, Франція має яскраво виражені ознаки реституційної моделі, Японія здійснює акцент на ресоціалізацію неповнолітніх. Однак, в той же час у профілактичних системах високорозвинених країн ми помічаємо й ознаки інших підходів. Так, у Німеччині, окрім ресоціалізації, увага приділяється й каральному аспекту, а також розгалуженою є система взаємодії різних органів та установ. У Великобританії, де найвагомішу роль відіграє громада, є й високорозвинена ресоціалізаційна система. Японія, окрім методів ресоціалізації, не оминає увагою необхідність співпраці різних урядових структур.

Узагальнюючи вищенаведене, ми вважаємо, що ефективна система профілактики правопорушень неповнолітніх має поєднувати у собі ознаки різних концепцій: об’єднувати громадські ініціативи задля профілактики девіацій серед дітей, мати структуровану систему ресоціалізації, у якій співпрацюють між собою різні державні установи, не уникати можливості відновлювального правосуддя, що $€$ однією із сутнісних ознак реституційного підходу, в той же час за необхідності до правопорушника мають бути застосовані каральні заходи.

Зважаючи на досвід впровадження сис- 
теми профілактики в зарубіжних країнах найбільш перспективним для запровадження в Україні, на нашу думку, є позитивний досвід Германії та Франції, де принцип індивідуального підходу до неповнолітніх правопорушників виражений у найбільш сприятливій формі, в тому числі й на структурному рівні. Мова йде про створення в системі правоохоронних органів підрозділів, які б представляли структуру створену з числа кваліфікованих педагогів, психологів, а також інших вузькопрофільних спеціалістів.

\section{Перелік використаних джерел:}

1. Бакаев А. А. Система профилактики правонарушений несовершеннолетних [учеб. пособ.]. М. : Логос, 2004. $218 \mathrm{c}$.

2.Бахрах Д. Н. Административное право : [учеб. для вуз.]. М. : БЕК, 1996. 368 с.

3.Брэбан Г. Французское административное право : [пер. с фр.] / под ред. С. В. Боботова. М. : Прогресс, $1988.488 \mathrm{c}$.

4.Денисов С. Ф. Детермінанти злочинності і моделі кримінологічної превенції злочинів молоді : монографія. Запоріжжя : Вид-во КПУ, 2010. 395 с.

5.Кудрявцева Н. И. Ювенальная юстиция в России и Франции : сравнительная характеристика : [учеб.метод. пособ. для студ. юрид. фак.]. Курск : Регион. открытый соц. ин-т, 2003. 105с.

6.Фризен П. Д. Административно-правовое предупреждение отдельных видов преступлений : дис. канд. юрид. наук : 12.00.08. Барнаул, 2004. 208 с.

7.Ювенальна юстиція : навчальний посібник / А. І. Гусєв, Ю. Б. Костова, Н. М. Крестовська та ін.; за ред. Н. М. Крестовської. Одеса : ОЮІ ХНУВС, 2006. 243 с.
8.Свириденко О. A. Individual and Psychological Determinants of Behavior of Juvenile Criminals Committed Grave Violent Crimes. Юридична психологія. 2017. № 1 (20). C. 54-61.

\section{References (Transliteration):}

1.Bakaev A. A. Sistema profilaktiki pravonarushenij nesovershennoletnih [Bakaev A. A. Juvenile delinquency prevention system]. M.: Logos, 2004. 218p. [in Russian]

2.Bahrah D.N. Administrativnoe pravo [Bahrah D.N. Administrative law]. M.: BEK, 1996. 368 p. [in Russian] 3.Breban G. Franzuzkoe administrativnoe pravo [Braban G. French administrative law]. M.: Progress. 1988. 488 p. [in Russian]

4.Denysov S.F. Determinanty zlochynnosti ta modeli kryminologichnoi prevenzii zlochyniv molodi [Denysov S.

F. Criminal determinants and criminological juvenile prevention models]. Zaporizhzhia: KPU, 2010. 395p. [in Ukrainian]

5.Kudryavzeva N.I. Juvenalnaya polizia v Rossii I Franzii: sravnitelnyj analiz [Kudryavzeva N.I. Juvenile police in Russia and France: comparative analysis]. Kyrsk, 2003. 105 p. [in Russian]

6.Frizen P.D. Administativno-pravovoe predypejdenie otdelnyh vidov prestyplenij [Frizen P.D. Administrative and legal prevention of individual kinds of crime]. $\mathrm{PhD}$ in Law thesis. Barnayl, 2004. 208 p. [in Russian]

7.Juvenalnaya justizia / I.A. Gusarev, U.B. Kostova, N.M. Krestovska and others. Odessa, 2006. 243 p. [in Ukrainian] 8.Svyrydenko O. [Свириденко O.] Individual and Psychological Determinants of Behavior of Juvenile Criminals Committed Grave Violent Crimes. [Yurydychna psykholohiia]. Юридична психологія. 2017. № 1 (20). С. 54-61 [in English]

(C) Мураненко К. Ю 


\section{Muranenko Kateryna}

Lecturer of Legal Psychology Department, National Academy of Internal Affairs, Kiev (Ukraine)

\section{JUVENILE DELINQUENCY PREVENTION IN FOREIGN COUNTRIES}

\section{ABSTRACT}

This article presents the description of juvenile delinquency prevention in foreign countries. It was determined the main effective characteristics which can be embodied in Ukrainian juvenile delinquency prevention system. Prevention systems of Great Britain, Germany, France, Japan were described in four basic concepts of youth crime prevention. There are repressive, resocialization, restitution and social integration approaches. Ukrainian juvenile delinquency prevention belongs to repressive model. The author shows that repressive approach can also be effective. Some aspects of repressive model manifested in German juvenile delinquency prevention. But the basis of this system is finding the reasons of committing crime. Delinquency prevention system in Germany, as in the Netherlands, combines repressive and re-socialization approaches. Juvenile delinquency prevention in Japan is an example of re-socialization model. But they pay attention to necessity of cooperation of different institutions. Legislation of Great Britain shows social integration model. France is an example of restitution approach. But all this delinquency prevention systems contain the signs of other approaches. So the most effective approach is combination of different models. At the same time juvenile delinquency prevention must be holistic and coordinated. The analysis of effective prevention systems shows that it is necessary to pay attention to legal field, specialized courts and special subjects of juvenile delinquency prevention.

It should be noted that the legislation on administrative responsibility and prevention of administrative offenses, in particular, the institution of administrative law, is inherent only in the countries of Eastern Europe. The legislation of Western countries under administrative responsibility provides for other relations. In accordance with the regulatory framework of Western European countries, all illegal acts fall under the concept of "criminal offenses", but they are considered offenses that do not entail consequences such as a criminal record. At the same time, in many countries of the world, not only crimes are prosecuted as norms of criminal law, but also acts that are not considered crimes in Ukrainian legislation.

Key words: juvenile delinquency, youth crime, crime prevention, foreign experience, repressive concept, re-socialization model, restitution model, social integration approach. 


\section{Мураненко Екатерина Юрьевна}

Преподаватель кафедры юридической психологии, Национальная академия внутренних дел, г. Киев (Украина)

\section{ЗАРУБЕЖНЫЙ ОПЫТ ПРОФИЛАКТИ- КИ ПРАВОНАРУШЕНИЙ СРЕДИ НЕСО- ВЕРШЕННОЛЕТНИХ}

Аннотация. В статье представлен анализ системы профилактики правонарушений среди несовершеннолетних и определены основные аспекты эффективной профилактики правонарушений, на которые необходимо обратить внимание в процессе становления системы профилактики правонарушений среди несовершеннолетних в Украине. Профилактические системы Великобритании, Франции, Германии, Японии описаны согласно четырем базовым концепциям превенции молодежной преступности. Определено, что система профилактики правонарушений несовершеннолетних в Украине является отражением традиционного карательно-репрессивного подхода, в отличие от профилактических систем зарубежных стран. Автор обращает внимание на то, что карательный аспект также является эффективным в профилактической деятельности. В Германии система профилактики правонарушений несовершеннолетних содержит проявления карательного аспекта, но в основе лежит поиск причин совершения преступлений. В Германии, как и в полиции Нидерландов, система профилактики правонарушений сочетает карательную и ресоциализонную мо- дели. Ярким примером ресоциализонной модели превенции молодежной преступности является Япония. Однако японская полиция отмечает необходимость взаимодействия разных органов и структур. Общественноинтеграционная модель отражается в законодательстве Великобритании. Франция является примером реституционной модели. В то же время, в этих системах профилактики наблюдаются признаки других подходов. То есть эффективным является сочетания разных моделей превенции молодежной преступности, при этом система профилактики правонарушений должна быть целостной и скоординированной. Анализ эффективных профилактических систем указывает на необходимость обратить внимание на такие составляющие как правовое поле, специализированные суды и специальные субъекты профилактики правонарушений несовершеннолетних.

Следует отметить, что законодательство об административной ответственности и профилактика административных правонарушений, в частности, институт административного права, присущ только странам Восточной Европы. Законодательство стран Запада под административной ответственностью предусматривает другие отношения. В соответствии с нормативно-правовой базой стран Западной Европы, все противоправные деяния подпадают под понятие «уголовные правонарушения», но в них выделяются проступки, которые не влекут за собой таких последствий 
как судимость. При этом нормами уголовного права во многих странах мира преследуются не только преступления, но и деяния, которые в украинском законодательстве преступлениями не считаются.

Ключевые слова: правонарушения несовершеннолетних, молодежная преступность, профилактика правонарушений, зарубежный опыт, карательно-репрессивная модель, ресоциализационная парадигма, реституционный подход, общественноинтеграционная модель. 